\title{
The Influence of Oxide Content on the Properties of Fly Ash/ Slag Geopolymer Mortars Activated with $\mathrm{NaOH}$
}

\author{
Erion Luga1*, Klaudio Peqini' ${ }^{2,3}$ \\ 1 Department of Civil Engineering, Faculty of Architecture and Engineering, EPOKA University, 1039 Tirana, Albania \\ ${ }^{2}$ Department of Physics, Faculty of Natural Sciences, University of Tirana, Blvd. Zogu I, Nr. 25, Tirana, Albania \\ ${ }^{3}$ Department of Computer Engineering, Faculty of Architecture and Engineering, EPOKA University, 1039 Tirana, Albania \\ * Corresponding author, e-mail: eluga@epoka.edu.al
}

Received: 14 May 2019, Accepted: 24 October 2019, Published online: 10 December 2019

\begin{abstract}
The actual study is an attempt to analyze the influence of the main oxides on the behavior of heat cured fly ash/ slag blend geopolymer mortars activated with sodium hydroxide ( $\mathrm{NaOH})$. Fly ash and slag were decomposed into oxides and analyzed in oxide basis. Polynomial models for mortar flow workability and compressive strength were built based on 40 design points with different; oxide ratios, water content, $\mathrm{NaOH}$ levels and curing temperatures normalized appropriately. The same data were also modelled and analyzed in Design Expert package program Response Surface method using the historical data feature. The models show to be very stable as the error values are several orders of magnitude smaller compared to the respective coefficients. It was observed that main oxides such as $\mathrm{CaO}$, $\mathrm{MgO}$ and $\mathrm{SiO}_{2}$ play an important role on the compressive strength of the mortars. On the other hand, both the methods used to build the models resulted in same equations, which indicates the consistency between the two approaches.
\end{abstract}

Keywords

fly ash, slag, silica fume, geopolymer, oxides

\section{Introduction}

Industrial waste storages such as GGBFS-Ground granulated blast furnace slag- and FA-fly ash- constitute an important environmental problem. Even though they have been used for decades as artificial pozzolans or blended with Portland cement, still only $20-30 \%$ of slag [1], and $50-55 \%$ of fly ashes [2] are being used, and the rest of them is occupying large landfill areas. Both slag and fly ash contain high percentages of amorphous silica and alumina making them a good source of suitable material to be used for the production of alkali activated mortars or concrete [3-5]. Known also as geopolymers, they are produced when materials containing alumina and silica react with alkaline solutions, producing aluminosilicate structures [6]. This process results not only in making use of a considerable amount of these industrial wastes, but also in the production of high-performance binders [7]. Geopolymers have a three-dimensional alumino-silicate structure in amorphous state with properties similar to ceramics [8,9]. Different studies report about the use of liquid sodium silicate, sodium metasilicate, sodium hydroxide and sodium carbonate as alkali activators to produce geopolymer mortars or concrete [10-12]. It has been reported also that curing temperature plays an important role on the alkali activation rate of materials such as fly ash and slag [1, 13-15]. Heat curing is very effective in improving the microstructure, reducing drying shrinkage, and compressive strength of geopolymer concretes, activated with $\mathrm{NaOH}$ and $\mathrm{Na}_{2} \mathrm{SiO}_{3}$ [16]. The best curing method might be different and related to the type of activator used. For example, dry heat curing is recommended for sodium hydroxide, but not for water glass systems since it tends to delay the reaction rate. On the other hand, steam curing shows intermediate strength between covered curing and dry curing [17]. It was also reported that increasing the slag percentage in alkali activated slag/fly ash mortars resulted in higher compressive strength [18]. The oxide composition of fly ash/slag shows to play an important role in the strength development of geopolymers. For normal cured geopolymers it shows to be strongly related to the $\mathrm{CaO}$ content and its ratio to $\mathrm{SiO}_{2}$ and $\mathrm{Al}_{2} \mathrm{O}_{3}$, whereas lower correlation values are obtained from heat cured mortars activated with sodium metasilicate $[19,20]$. 
Different studies have investigated the production factors of alkali activated materials separately from each-other. In their previous study the authors investigated and assessed properties of alkali activated fly ash/ slag blends activated in different water to binder ratios, $\mathrm{NaOH}$ levels and curing temperatures, considering also the interaction between the factors and developed empirical models to predict the mortar properties [15]. The models were very accurate in fly ash/slag bases, but being industrial by-products, fly ash and slag can have very different chemical composition and oxide percentages depending on factors such as: raw material properties, technology of power plant or blast furnace etc [3, 21-23]. This study is an attempt to develop universal models based on the content of some of the main oxides such as $\mathrm{CaO}, \mathrm{MgO}$ and $\mathrm{SiO}_{2}$ or/and $\mathrm{Al}_{2} \mathrm{O}_{3}$ in the fly ash/ slag blend considered to be the most important ones in the geopolymerization process.

\section{Materials}

\subsection{Ground granulated blast-furnace slag (GGBFS) and Fly ash (FA)}

In this study there were used GGBFS produced in Iron-Steel Factory of Iskenderun, Turkey and FA from Sugozu thermal power plant Adana, Turkey. The specific gravity of GGBFS is $2.81 \mathrm{~g} / \mathrm{cm}^{3}$ and Blaine specific surface of $4250 \mathrm{~cm}^{2} / \mathrm{g}$ and the hydraulic activity index according to ASTM C989 [24] classified as a grade of 80 slag. Whereas the Class F fly ash has a specific gravity of $2.39 \mathrm{~g} / \mathrm{cm}^{3}$ and a Blaine value of $2900 \mathrm{~cm}^{2} / \mathrm{g}, \mathrm{SiO}_{2}+\mathrm{Al}_{2} \mathrm{O} 3+\mathrm{Fe}_{2} \mathrm{O}_{3}>70 \%, \mathrm{CaO}<10 \%$ according to EN 450-1 [25] and 28 days pozzolanic activity of 78 according to ASTM C618-94a [26]. In Table 1 are reflected the chemical compositions of GGBFS and FA.

\subsection{Sodium hydroxide and sand}

The sodium hydroxide $(\mathrm{NaOH})$ was provided from Akca Chemical Company, Istanbul, Turkey. The chemical composition of sodium hydroxide is $98 \% \mathrm{NaOH}$ and a small amount of Impurities. Whereas the mortar mixtures were prepared with Rilem-Cembureau Standard dry sand provided from Trakya Set Çimento Sanayi T.A.S. Cement Factory, Turkey.

\section{Methodology}

\subsection{Experimental design}

The mix designs of the alkali activated fly ash/slag blend mortars were prepared with 'Combined Design' method of Design Expert 8 package program [15, 27]. The mortars were produced with $1350 \mathrm{~g}$ RILEM sand and $450 \mathrm{~g}$ of fly ash/slag in conformity to TS-EN 196-1 [28], 180-225 g water and 50-150 g NaOH, and cured in different temperatures ranging from 50 to $100^{\circ} \mathrm{C}$ for $72 \mathrm{hrs}$. The design points are not defined according to a predefined trend, but they scan the whole design space and are used to model the variations for each response [15]. The mortars were then tested for flow workability and compressive strength, which were considered as the most important properties of the mortars to be investigated. Fly ash and slag were decomposed into oxides and analyzed in oxide basis.

\subsection{Analysis of polynomial models}

Polynomial models of flow workability and compressive strength were developed from the experimental results of the 40 test series with different oxide ratios, $\mathrm{NaOH}$, water levels and curing temperatures as shown in Table 2. A system of algebraic equations, involving polynomials, using the data at disposal was set up, where the coefficients of the models are the unknowns. Generally, there are more equations than unknowns, so the system is over-determined and consequently the least-squares method is applied. The actual system is then inverted thus obtaining the values of the coefficients. Then the errors of these coefficients are calculated following the standard procedure of the least-squares [29]. This method has been accurately applied by the authors also in other studies [30]. The same data were also modelled and analyzed in Design Expert package program's Response Surface method, using the "Historical Data" feature.

For modelling purposes, the oxide ratios, water content, $\mathrm{NaOH}$ and curing temperature for each of the 40-test series were considered as factors. However not all the oxides present in the mixture are of the same importance. In the literature it is reported that geopolymerization process results in the formation of $\mathrm{C}-(\mathrm{A})-\mathrm{S}-\mathrm{H}$

Table 1 GGBFS and FA chemical compositions (\%)

\begin{tabular}{lcccccccccc}
\hline Oxide & $\mathrm{SiO}_{2}$ & $\mathrm{Al}_{2} \mathrm{O}_{3}$ & $\mathrm{Fe}_{2} \mathrm{O}_{3}$ & $\mathrm{CaO}$ & $\mathrm{MgO}$ & $\mathrm{SO}_{3}$ & $\mathrm{~K}_{2} \mathrm{O}$ & $\mathrm{Na}_{2} \mathrm{O}$ & 0.99 & 0.76 \\
\hline GGBFS & 36.7 & 5.20 & 0.98 & 32.61 & 10.12 & 0.99 & 2.88 \\
FA & 61.81 & 19.54 & 7.01 & 1.77 & 2.56 & 0.31 & 0.99 & 2.43 & 2.20 \\
\hline
\end{tabular}


( $\mathrm{CaO}-\mathrm{Al}_{2} \mathrm{O}_{3}-\mathrm{SiO}_{2}-\mathrm{H}_{2} \mathrm{O}$ calcium aluminosilicate hydrate) or M-(A)-S-H ( $\mathrm{MgO}-\mathrm{Al}_{2} \mathrm{O}_{3}-\mathrm{SiO}_{2}-\mathrm{H}_{2} \mathrm{O}$ Magnesium alumino-silicate hydrate) typical of alkali-activated slag systems and $\mathrm{N}-(\mathrm{A})-\mathrm{S}-\mathrm{H}\left(\mathrm{Na}_{2} \mathrm{O}-\mathrm{Al}_{2} \mathrm{O}_{3}-\mathrm{SiO}_{2}-\mathrm{H}_{2} \mathrm{O}\right.$ sodium alumino-silicate hydrate) in fly ash based systems [31-33]. This shows that calcium-based, and magnesium-based gel formations are independent from each other and can develop simultaneously, whereas the involvement of aluminium oxide is optional, that is why only $\mathrm{CaO}, \mathrm{MgO}$ and $\mathrm{SiO}_{2}$ were considered important for the analysis represented in the model as $x_{1}-(\mathrm{CaO}+\mathrm{MgO}) / \mathrm{SiO}_{2}$. Based on previous research pointing out that the concentration of $\mathrm{NaOH}$ plays a very crucial role on the strength development of fly ash and slag geopolymer mortars, it was considered as an important factor for the model, represented as $x_{2}[1,15]$. On the other hand, water/solid phase represented as $x_{3}$, is well-known for its effect on the properties of hydraulic binders, however it was considered for the model in order to understand its combined effect with the other factors. Curing temperature represented in the model as $x_{4}$ is considered very important for the development of the microstructure and compressive strength of geopolymer concretes, activated with $\mathrm{NaOH}$ [16]. In order not to use different units in the same model all the four variables were normalized appropriately. The normalized variables as given in Table 2. take values in a specific set such as: $x_{1}-(\mathrm{CaO}+\mathrm{MgO}) / \mathrm{SiO}_{2}$ between 0.07 and $1.163, x_{2}$ - ratio of $\mathrm{Na}+/$ solid phase of the binder from $0.064(6.4 \%)$ to $0.192(19.2 \%), x_{3}-$ water/solid phase ratio between $0.4-0.5$ and $x_{4}$ - normalized temperature equal to curing temperature $/ 100{ }^{\circ} \mathrm{C}$. As the temperature ranges from $50-100{ }^{\circ} \mathrm{C}$ the normalized values range from $0.5-1$. Then the empirical models of normalized variables and test results were developed as polynomial equations up to the second order.

Initially a model for the workability of the mortar was built. The values of workability were organized in the vector $\mathbf{y}$ and one element being $y_{i}$. Therefore

$$
y_{i}=p+q x_{1}+r x_{3} .
$$

The quadratic model was also considered, but the results were very similar indicating that the linear version is quite accurate. On the other hand, as the curing process does not affect the fresh mortar it was not considered for modelling. Also, it was previously observed that $\mathrm{NaOH}$ didn't show any notable effect on flow workability, for that reason it was not taken in consideration. That is why in the equation of flow workability were included only the
$\mathrm{CaO}+\mathrm{SiO}_{2} / \mathrm{MgO}$ ratio and water content as factors affecting the workability of the mixture. The system Eq. (1) can be written in matrix form as

$\mathbf{y}=\mathbf{A v}$.

Here $\mathbf{A}$ is the matrix of the values of the normalized variables and $\mathrm{v}$ is the vector of the model's coefficients. The coefficients are calculated by matrix inversion

$\mathbf{v}=\mathbf{A}^{-1} \mathbf{y}$

where $\mathbf{A}^{-1}$ is the inverse of matrix $\mathbf{A}$. For the compressive strength it was considered the quadratic model. In this case the normalized variable pertaining to all the four factors have been considered. Therefore

$$
\begin{aligned}
& y_{i}=a x_{1}+b x_{2}+c x_{3}+d x_{4}+e x_{1} x_{2}+f x_{1} x_{3}+g x_{1} x_{4} \\
& +h x_{2} x_{3}+i x_{2} x_{4}+j x_{3} x_{4}+k x_{1}^{2}+l x_{2}^{2}+m x_{3}^{2}+h x_{4}^{2} .
\end{aligned}
$$

The terms from ' $x_{1}$ ' to ' $x_{4}^{\prime}$ ' refer to: $x_{1}-(\mathrm{CaO}+\mathrm{MgO}) / \mathrm{SiO}_{2}$, $x_{2}-\mathrm{Na}^{+} /$solid phase of the binder, $x_{3}-$ water/solid phase and $x_{4}$-curing temperature $/ 100{ }^{\circ} \mathrm{C}$. There is no free term in this equation because it was found that it destabilized the model by yielding complex coefficients. A matrix equation similar to Eq. (2) is obtained and the inversion is carried out as in Eq. (3).

\subsection{Preparation and curing of the mortar samples}

The mortar samples were prepared and cast into $40 \times 40 \times 160 \mathrm{~mm}$ prismatic moulds in compliance with the TS-EN 196-1 [28] standard. The mortars were placed in the mortar moulds and put in the oven for curing. The curing temperatures of each mix are shown in Table 2. The mortar specimens were dry cured [17] for 3 days in the oven. After removing from the oven, they were cooled to room temperature then removed from the moulds and tested.

\subsection{Flow workability test}

The flow workability of the fresh mortars was determined in compliance to TS EN 1015-3 standard [34]. The test specimen is prepared in the conical mould of $60 \mathrm{~mm} \pm 0.5 \mathrm{~mm}$ upper base and $100 \mathrm{~mm} \pm 0.5 \mathrm{~mm}$ lower base diameters. After positioning the mould in the middle of the test table, it is filled with mortar in two layers, hitting each of them for ten times with a wooden rod. In 15 seconds, the mould is slowly removed, and the table is dropped 15 times. The flow workability is the average value of two perpendicular diameters of the mortar. 


\subsection{Compressive strength test}

The compressive strength test is performed on $40 \times 40 \mathrm{~mm}$ area at a loading rate of $500 \mathrm{~N} / \mathrm{s}$. The mathematical average of the six tested samples is the compressive strength in accordance with TS EN 196-1 [28].

\section{Results and discussion}

4.1 Results for polynomial models

The numerical calculations were done by adopting the data shown in Table 2. The codes for the models are written and run in the MATLAB platform using matrix calculation

Table 2 Production parameters and experimental test results used for the polynomial modelling

\begin{tabular}{|c|c|c|c|c|c|c|}
\hline \multirow[b]{2}{*}{ No } & \multicolumn{4}{|c|}{ Normalized values used for the polynomial modeling } & \multicolumn{2}{|c|}{ Experimental test results } \\
\hline & $\mathrm{X}_{1}$ & $\mathrm{X}_{2}$ & $\mathrm{X}_{3}$ & $\mathrm{X}_{4}$ & Flow Workability (mm) & Compressive Strength. (MPa) \\
\hline 1 & 0.070 & 0.147 & 0.400 & 1.00 & 225 & 54.9 \\
\hline 2 & 0.470 & 0.115 & 0.460 & 0.50 & 230 & 12.5 \\
\hline 3 & 0.070 & 0.116 & 0.440 & 0.50 & 270 & 9.2 \\
\hline 4 & 0.427 & 0.150 & 0.485 & 0.67 & 215 & 14.6 \\
\hline 5 & 0.471 & 0.192 & 0.460 & 0.80 & 200 & 19.7 \\
\hline 6 & 1.163 & 0.064 & 0.400 & 1.00 & 110 & 45.0 \\
\hline 7 & 0.467 & 0.192 & 0.400 & 0.50 & 155 & 27.0 \\
\hline 8 & 1.163 & 0.192 & 0.400 & 0.50 & 115 & 42.2 \\
\hline 9 & 0.471 & 0.192 & 0.460 & 0.80 & 198 & 24.6 \\
\hline 10 & 0.772 & 0.128 & 0.410 & 0.54 & 150 & 22.2 \\
\hline 11 & 1.163 & 0.064 & 0.400 & 0.50 & 108 & 20.6 \\
\hline 12 & 1.163 & 0.064 & 0.500 & 0.50 & 170 & 13.5 \\
\hline 13 & 0.476 & 0.064 & 0.435 & 1.00 & 175 & 24.3 \\
\hline 14 & 0.481 & 0.064 & 0.500 & 0.68 & 210 & 10.7 \\
\hline 15 & 0.070 & 0.192 & 0.400 & 0.50 & 225 & 2.7 \\
\hline 16 & 0.070 & 0.064 & 0.400 & 0.68 & 220 & 11.2 \\
\hline 17 & 0.470 & 0.115 & 0.400 & 0.80 & 165 & 30.8 \\
\hline 18 & 0.470 & 0.115 & 0.460 & 0.50 & 225 & 12.2 \\
\hline 19 & 0.070 & 0.192 & 0.500 & 1.00 & 300 & 50.1 \\
\hline 20 & 0.070 & 0.115 & 0.500 & 0.80 & 290 & 24.5 \\
\hline 21 & 0.479 & 0.064 & 0.400 & 0.50 & 140 & 15.4 \\
\hline 22 & 0.847 & 0.128 & 0.450 & 1.00 & 180 & 45.7 \\
\hline 23 & 0.070 & 0.064 & 0.464 & 1.00 & 260 & 9.5 \\
\hline 24 & 0.470 & 0.115 & 0.400 & 0.80 & 160 & 33.2 \\
\hline 25 & 0.070 & 0.064 & 0.500 & 0.50 & 290 & 10.0 \\
\hline 26 & 1.163 & 0.192 & 0.500 & 0.68 & 180 & 32.3 \\
\hline 27 & 0.070 & 0.192 & 0.440 & 0.80 & 250 & 29.1 \\
\hline 28 & 0.476 & 0.064 & 0.435 & 1.00 & 175 & 23.3 \\
\hline 29 & 0.470 & 0.192 & 0.400 & 1.00 & 160 & 57.1 \\
\hline 30 & 0.481 & 0.192 & 0.500 & 0.50 & 215 & 14.5 \\
\hline 31 & 1.163 & 0.109 & 0.500 & 1.00 & 182 & 38.6 \\
\hline 32 & 0.070 & 0.192 & 0.500 & 0.50 & 300 & 2.9 \\
\hline 33 & 0.773 & 0.121 & 0.446 & 0.73 & 170 & 24.5 \\
\hline 34 & 1.163 & 0.064 & 0.460 & 0.80 & 140 & 22.7 \\
\hline 35 & 0.484 & 0.146 & 0.500 & 1.00 & 230 & 34.1 \\
\hline 36 & 1.163 & 0.192 & 0.434 & 1.00 & 133 & 57.1 \\
\hline 37 & 0.481 & 0.064 & 0.500 & 0.68 & 210 & 11.5 \\
\hline 38 & 0.252 & 0.179 & 0.450 & 0.51 & 210 & 15.7 \\
\hline 39 & 1.163 & 0.141 & 0.460 & 0.50 & 150 & 24.8 \\
\hline 40 & 1.163 & 0.139 & 0.400 & 0.79 & 120 & 44.0 \\
\hline
\end{tabular}


Table 3 Coefficients and errors for the three polynomial models

\begin{tabular}{|c|c|c|c|c|c|}
\hline \multicolumn{3}{|c|}{ Workability } & \multicolumn{3}{|c|}{ Compressive strength } \\
\hline \multicolumn{2}{|c|}{ Coefficients } & \multirow{2}{*}{$\frac{\text { Errors }}{0.05}$} & \multicolumn{2}{|c|}{ Coefficients } & \multirow{2}{*}{$\frac{\text { Errors }}{0.8}$} \\
\hline $\mathrm{o}$ & -46.9 & & $\mathrm{a}$ & 58.0 & \\
\hline $\mathrm{p}$ & -99.6 & 0.01 & $\mathrm{~b}$ & 371.0 & 7.1 \\
\hline \multirow[t]{12}{*}{ q } & 664.8 & 0.10 & $\mathrm{c}$ & -146.1 & 4.2 \\
\hline & & & d & 29.5 & 2.0 \\
\hline & & & $\mathrm{e}$ & 31.2 & 1.2 \\
\hline & & & f & -108.9 & 1.5 \\
\hline & & & g & -14.8 & 0.3 \\
\hline & & & $\mathrm{h}$ & -495.1 & 12.1 \\
\hline & & & $\mathrm{i}$ & 310.8 & 2.5 \\
\hline & & & $\mathrm{j}$ & -225.4 & 3.2 \\
\hline & & & $\mathrm{k}$ & 8.6 & 0.2 \\
\hline & & & 1 & -1076.2 & 13.8 \\
\hline & & & $\mathrm{m}$ & 375.5 & 7.3 \\
\hline & & & $\mathrm{n}$ & 59.6 & 0.9 \\
\hline
\end{tabular}

features. The coefficients as well as the respective errors are shown in Table 3. As it can be seen from the table the coefficients are one or several orders of magnitude larger than the respective errors. Equations (5) and (6) present respectively the equation obtained for workability and compressive strength.

Flow Workability:

$y_{i}=-46.9-99.6 x_{1}+664.8 x_{3}$;

Compressive strength:

$y_{i}=58.0 x_{1}+371.0 x_{2}-146.1 x_{3}+29.5 x_{4}+31.2 x_{1} x_{2}$

$-108.9 x_{1} x_{3}-14.8 x_{1} x_{4}-495.1 x_{2} x_{3}+310.8 x_{2} x_{4}$

$-225.4 x_{3} x_{4}+8.6 x_{1}^{2}-1076.2 x_{2}^{2}+375.5 x_{3}^{2}+59.6 x_{4}^{2}$.

It should be stressed that higher quantity of data would improve the polynomial method results [30]. However, from the results above, it can be deduced that the polynomial method is very reliable in the design of geopolymer mortars. The two terms of the flow workability model are independent from each-other, whereas the terms of the compressive strength model are interrelated, which means that the removal of any of the terms from the model will change the values of the coefficients.

In order to find the optimal results, it was constructed a grid of experimental points (each point being a set of three or four numbers pertaining to each of the normalized variables) in the specific range of the normalized variables. The total number of grid points was limited due to shortage of computational capabilities. However, for the workability model the grid contained 400 points whereas the compressive strength model contained 160000 points. Then the coefficients found from the matrix inversion show in Table 3 were used to calculate the predictions of each model.

The numerical calculations show that: the flow workability the optimal value is 278.5 and is achieved for $x_{1}=0.070$, and $x_{3}=0.500$; the compressive strength the optimal value is 71.9 that is achieved for $x_{1}=1.163, x_{2}=0.192, x_{3}=0.400$ and $x_{4}=1.000$;

The obtained results show some interesting implications. It is clear that low $(\mathrm{CaO}+\mathrm{MgO}) / \mathrm{SiO}_{2}$ ratio and high water content contribute to high workability. On the other hand, the highest curing temperature maximizes the compressive strength. It is observed that a relatively high value of $(\mathrm{CaO}+\mathrm{MgO}) / \mathrm{SiO}_{2}$ ratio, low values of water content and high $\mathrm{NaOH}$ content as well as high curing temperature yield optimal mechanical characteristics for the mortars.

\subsection{Response surface method}

The same data used for the polynomial modelling shown in Table 2 were also analyzed in Design Expert package program's Response Surface method, using the "Historical Data" feature.

\subsubsection{Flow workability model analysis}

Fig. 1 illustrates the effect of $(\mathrm{CaO}+\mathrm{MgO}) / \mathrm{SiO}_{2}$ and water/binder ratio on the flow workability of the geopolymer mortars. As it can be seen from the graph and from the Eq. (7) the only parameters that affect the flow workability of the mortars are the $(\mathrm{CaO}+\mathrm{MgO}) / \mathrm{SiO}_{2}$ and water/binder ratio. The maximum flow workability values are reached when the $(\mathrm{CaO}+\mathrm{MgO}) / \mathrm{SiO}_{2}=>$ (minimum) and water/ binder $=>$ (maximum)

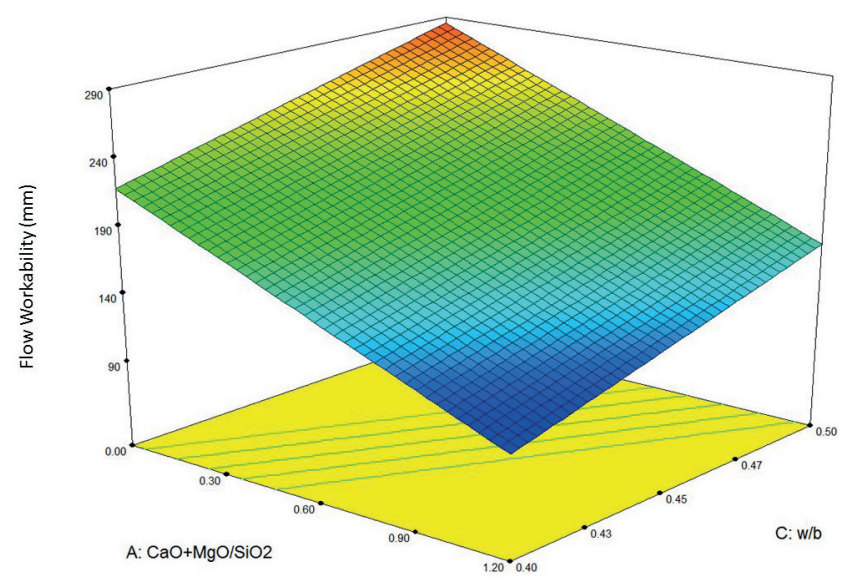

Fig. 1 Flow workability graph 
Flow Workability $=-47.5-99.55 x_{1}+666.03 x_{3}$.

As it can be seen from Fig. 1 and from Eq. (7) the function fits a linear model. It indicates that flow workability of the mortars increases linearly as the $(\mathrm{CaO}+\mathrm{MgO}) / \mathrm{SiO}_{2}$ ratio decreases which in this case means decreasing of slag and increasing of fly ash content. Literature also indicates the same trend [35-37]. Because $\mathrm{CaO}$ and $\mathrm{MgO}$ mainly come from ground granulated blast furnace slag, whereas $\mathrm{SiO}_{2}$ mainly comes from fly ash. Water to binder ratio also shows to be an important factor for the flow workability. Even though in the beginning the $\mathrm{NaOH} /$ binder was considered as a factor the model shows that $\mathrm{NaOH}$ content in the given range does have any notable effect on flow workability [38]. It should not be forgotten that the fineness of the binding materials plays a very important role in the flow workability of the mortars. Blaine specific surface of GGBFS in this case is $4250 \mathrm{~cm}^{2} / \mathrm{g}$ whereas fly ash has a Blaine value of $2900 \mathrm{~cm}^{2} / \mathrm{g}$. Clearly the coefficients are very similar to that of the polynomial linear model indicating consistency between these two approaches.

\subsubsection{Analysis of compressive strength model}

Equation (8) shows the variation of the compressive strength values with regard to $\mathrm{X}_{1}-(\mathrm{CaO}+\mathrm{MgO}) / \mathrm{SiO}_{2}$, $\mathrm{X}_{2}-\mathrm{Na} /$ binder, $\mathrm{X}_{3}$-Water / binder ratios and $\mathrm{X}_{4}$ - Curing temperature. In the case of compressive strength, the coefficients for both models are identical indicating greater consistency than the flow workability case where the coefficients are slightly different.

$$
\begin{aligned}
& \text { Compressive Strength }=58 x_{1}+371 x_{2}-146.1 x_{3}+29.5 x_{4} \\
& +31.2 x_{1} x_{2}-108.9 x_{1} x_{3}-14.8 x_{1} x_{4}-495.1 x_{2} x_{3}+310.8 x_{2} x_{4} \\
& -225.4 x_{3} x_{4}+8.6 x_{1}^{2}-1076.2 x_{2}^{2}+375.5 x_{3}^{2}+59.6 x_{4}^{2} .
\end{aligned}
$$

The figures below illustrate the compressive strength variation for different combinations of the variables.

Fig. 2 illustrates the effect of $(\mathrm{CaO}+\mathrm{MgO}) / \mathrm{SiO}_{2}$ and $\mathrm{Na} /$ binder ratio on the compressive strength values for minimum water to binder ratio $(\mathrm{w} /$ bind $=0.4)$ and maximum temperatures $=100^{\circ} \mathrm{C}$. As it can be seen from the graph, $\mathrm{Na} /$ binder ratio has a very important role in the compressive strength values of the mortars. Also, similarly to the polynomial model the maximum compressive strength values are reached when the $(\mathrm{CaO}+\mathrm{MgO}) / \mathrm{SiO}_{2}$ is equal to 1.16 (maximum).

Taking in consideration that the reaction mechanisms of slag systems result in the formation of C(M)-(A)-S-H and the fly ash based systems in the formation of

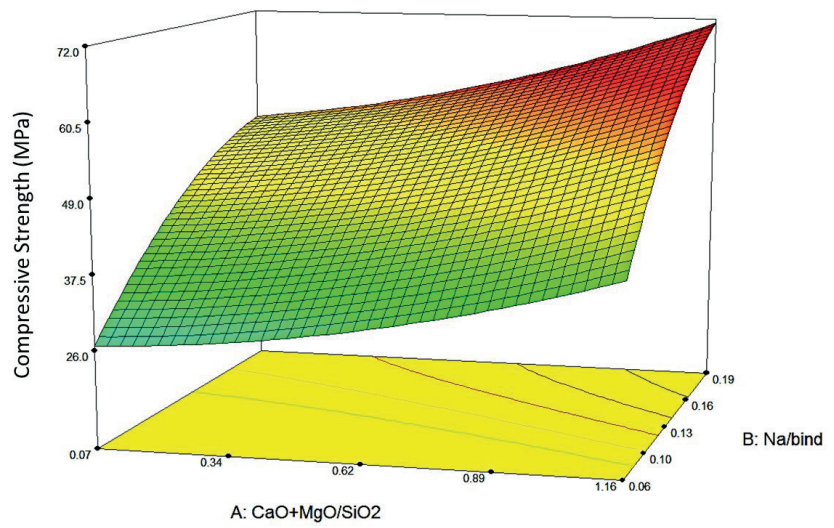

Fig. 2 Compressive strength development related to the $(\mathrm{CaO}+\mathrm{MgO}) / \mathrm{SiO}_{2}$ and $\mathrm{Na} /$ binder ratio

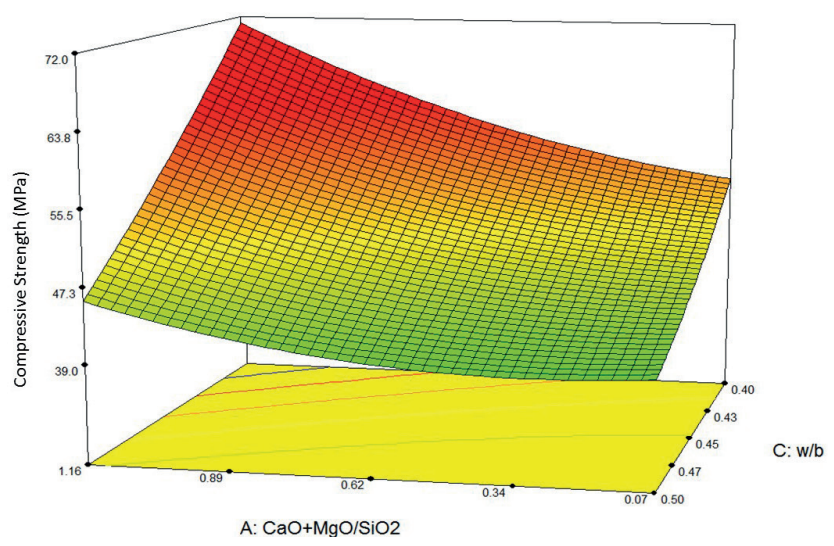

Fig. 3 Compressive strength development related to the $(\mathrm{CaO}+\mathrm{MgO}) / \mathrm{SiO}_{2}$ and water/binder ratio

$\mathrm{N}-(\mathrm{A})-\mathrm{S}-\mathrm{H}$ [31-33] it can be derived that $\mathrm{NaOH}$ acts as a catalyser for the first case and as a reactant in the second one. Literature reports that the production of low alkaline and high temperature fly ash/slag blend geopolymers [39] in this case at a $0.6-0.8(\mathrm{CaO}+\mathrm{MgO}) / \mathrm{SiO}_{2}$ ratio shows to be a good option for mortars of compressive strength up to $60 \mathrm{MPa}$. Previous researches also point out that the concentration of $\mathrm{NaOH}$ plays a very crucial role on the strength development of fly ash and slag geopolymer mortars [1, 14, 40, 41].

Fig. 3 shows the compressive strength development for different $(\mathrm{CaO}+\mathrm{MgO}) / \mathrm{SiO}_{2}$ and water/binder ratios. It indicates that the compressive strength decreases as $(\mathrm{CaO}+\mathrm{MgO}) / \mathrm{SiO}_{2}$ and water/binder ratios decrease. Other studies also report that increasing the alkaline liquid content results in the decreasing of compressive strength of alkali-activated concretes or mortars [36, 39].

Fig. 4 illustrates the effect of $(\mathrm{CaO}+\mathrm{MgO}) / \mathrm{SiO}_{2}$ and curing temperature on the compressive strength values. The results show that Curing temperature is a very important factor in the activation of fly ash/slag geopolymer mortars. 


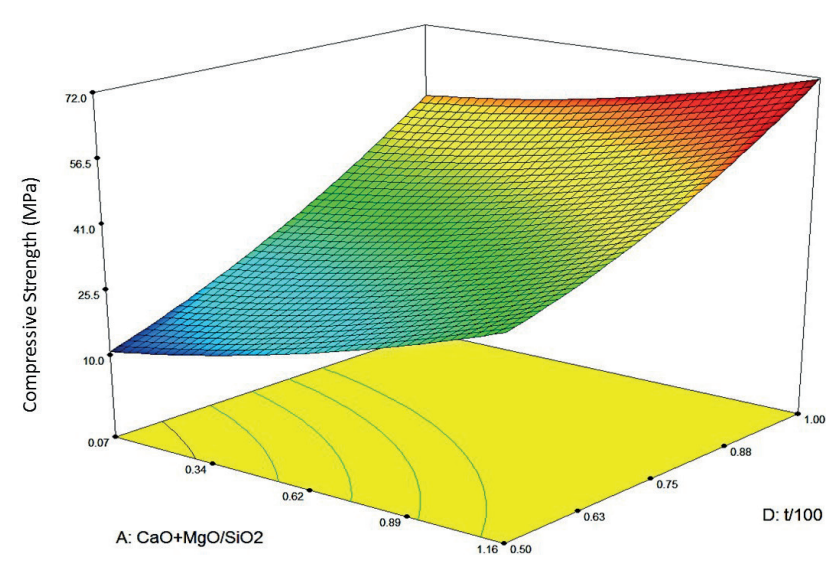

Fig. 4 Compressive strength development related to the $(\mathrm{CaO}+\mathrm{MgO}) / \mathrm{SiO}_{2}$ and Curing temperature

The strength values increase considerably as the curing temperature increases. Especially for low $(\mathrm{CaO}+\mathrm{MgO}) /$ $\mathrm{SiO}_{2}$ mixtures which indicates that curing temperature is a crucial factor in the activation of fly ash with $\mathrm{NaOH}$. Literature also reports that fly ash activated with $\mathrm{NaOH}$ shows very little or no activation products for curing temperatures up to $50{ }^{\circ} \mathrm{C}[1,14,39]$.

\section{References}

[1] Puertas, F., Martínez-Ramírez, S., Alonso, S., Vázquez, T. "Alkaliactivated fly ash/slag cements: Strength behaviour and hydration products", Cement and Concrete Research, 30(10), pp. 1625-1632, 2000.

https://doi.org/10.1016/S0008-8846(00)00298-2

[2] Heidrich, C., Feuerborn H.-J., Weir, A. "Coal Combustion Products: A Global Perspective", In: 2013 World of Coal Ash (WOCA) Conference, Lexington, KY, USA, April, 22-25, 2013.

[3] Erdoğan, T. Y. "Admixtures for Concrete", METU Press, Ankara, Turkey, 1997.

[4] Atiş, C. D., Bilim, C. "Wet and dry cured compressive strength of concrete containing ground granulated blast-furnace slag", Building and Environment, 42(8), pp. 3060-3065, 2007.

https://doi.org/10.1016/j.buildenv.2006.07.027

[5] Sathonsaowaphak, A., Chindaprasirt, P., Pimraksa, K. "Workability and strength of lignite bottom ash geopolymer mortar", Journal of Hazardous Materials, 168(1), pp. 44-50, 2009 https://doi.org/10.1016/j.jhazmat.2009.01.120

[6] Wongpa, J., Kiattikomol, K., Jaturapitakkul, C., Chindaprasirt, P. "Compressive strength, modulus of elasticity, and water permeability of inorganic polymer concrete", Materials \& Design, 31(10), pp. 4748-4754, 2010.

https://doi.org/10.1016/j.matdes.2010.05.012

[7] Van Deventer, J. S. J., Provis, J. L., Duxson, P., Lukey, G. C. "Reaction mechanisms in the geopolymeric conversion of inorganic waste to useful products", Journal of Hazardous Materials, 139(3), pp. 506513, 2007.

https://doi.org/10.1016/j.jhazmat.2006.02.044

\section{Conclusions}

The actual study is an attempt to analyze the influence of the main oxides on the strength properties of heat cured fly ash/ slag blend geopolymer mortars activated with sodium hydroxide $(\mathrm{NaOH})$.

It was observed that main oxides such as $\mathrm{CaO}, \mathrm{MgO}$ and $\mathrm{SiO}_{2}$ play an important role in the mechanical characteristics of the mortars. On the other hand, both the ways used for the modelling of the compressive strength development of the geopolymer mortars resulted in almost the same equations, for flow workability and compressive strength.

On the other hand, the formation of N-(A)-S-H form the activation of high $\mathrm{SiO}_{2}$ with $\mathrm{NaOH}$ is strongly related to the curing temperature.

As a result, it can be concluded that the models can be used as reference to produce geopolymer mortars of different oxide composition.

\section{Acknowledgement}

We express our gratitude to the two anonymous reviewers for their observations and suggestions thus improving this paper.

[8] Davidovits, J. "Chemistry of geopolymeric systems, terminology", In: Proceedings of the 2nd International Conference, Géopolymère, Saint-Quentin, France, 1999, pp. 9-39.

[9] Davidovits, J. "Geopolymers: Man-Made Rock Geosynthesis and the Resulting Development of Very Early High Strength Cement", Journal of Materials education, 16(2-3), pp. 91-139, 1994.

[10] Davidovits, J., Davidovics, M. "Geopolymer: Room Temperature Ceramic Matrix for Composites", Ceramic Engineering and Science Proceedings, 9(7-8), pp. 835-842, 1988.

[11] Bakharev, T., Sanjayan, J. G., Cheng, Y.-B. "Alkali activation of Australian slag cements", Cement and Concrete Research, 29(1), pp. 113-120, 1999. https://doi.org/10.1016/S0008-8846(98)00170-7

[12] Atiş, C. D., Bilim, C., Çelik, Ö., Karahan, O. "Influence of activator on the strength and drying shrinkage of alkali-activated slag mortar", Construction and Building Materials, 23(1), pp. 548-555, 2009.

https://doi.org/10.1016/j.conbuildmat.2007.10.011

[13] Xie, Z., Xi, Y. "Hardening mechanisms of an alkaline-activated class F fly ash", Cement and Concrete Research, 31(9), pp. 1245-1249, 2001. https://doi.org/10.1016/S0008-8846(01)00571-3

[14] Atiş, C. D., Görür, E. B., Karahan, O., Bilim, C., Ilkentapar, S., Luga, E. "Very high strength (120 MPa) class F fly ash geopolymer mortar activated at different $\mathrm{NaOH}$ amount, heat curing temperature and heat curing duration", Construction and Building Materials, 96, pp. $673-678,2015$. https://doi.org/10.1016/j.conbuildmat.2015.08.089 
[15] Luga, E., Atis, C. D. "Optimization of heat cured fly ash/slag blend geopolymer mortars designed by "Combined Design" method: Part 1", Construction and Building Materials, 178, pp. 393-404, 2018.

https://doi.org/10.1016/j.conbuildmat.2018.05.140

[16] Bakharev, T., Sanjayan, J. G., Cheng, Y.-B. "Effect of elevated temperature curing on properties of alkali-activated slag concrete", Cement and Concrete Research, 29(10), pp. 1619-1625, 1999. https://doi.org/10.1016/S0008-8846(99)00143-X

[17] Kovalchuk, G., Fernández-Jiménez, A., Palomo, A. "Alkaliactivated fly ash: effect of thermal curing conditions on mechanical and microstructural development - Part II", Fuel, 86(3), pp. 315$322,2007$. https://doi.org/10.1016/j.fuel.2006.07.010

[18] Luga, E., Atiş, C. D. "Strength Properties of Slag/Fly Ash Blends Activated with Sodium Metasilicate and Sodium Hydroxide+Silica Fume", Periodica Polytechnica Civil Engineering, 60(2), pp. 223228, 2016.

https://doi.org/10.3311/PPci.8270

[19] van Jaarsveld, J. G. S., van Deventer, J. S. J., Lukey, G. C. "The characterisation of source materials in fly ash-based geopolymers", Materials Letters, 57(7), pp. 1272-1280, 2003. https://doi.org/10.1016/S0167-577X(02)00971-0

[20] Luga, E., Atis, C. D., Karahan, O., Ilkentapar, S., Gorur, E. B. "Strength properties of slag/fly ash blends activated with sodium metasilicate", Građevinar, 69(3), pp. 199-205, 2017. https://doi.org/10.14256/JCE.1468.2015

[21] Erdoğan, T. Y. "Materials of Construction", Metu Press, Ankara, Turkey, 2009.

[22] Mehta, P. K., Montero, P. J. M. "Concrete: Microstructure, Properties and Materials", 3rd ed., McGraw-Hill, New York, NY, USA, 2006.

[23] Neville, A. M. "Properties of Concrete", John Wiley \& Sons, London, UK, 2003.

[24] ASTM "ASTM C989 Standard Specification for Slag Cement for Use in Concrete and Mortars", In: Annual Book of ASTM Standards, ASTM International, West Conshohocken, PA, USA, 2014.

[25] CEN, "EN 450-1 Fly ash for concrete - Part 1: Definitions, specifi-cations and conformity criteria", European Committee for Standartization, Brussels, Belgium, 2012.

[26] ASTM "ASTM C618-94a Standard Specification for Coal and Fly Ash and Raw or Calcined Natural Pozzolan for Use as a Mineral Admixture in Portland Cement Concrete", In: Annual Book of ASTM Standards, ASTM International, West Conshohocken, PA, USA, 1997.

[27] Lundstedt, T., Seifert, E., Abramo, L., Thelin, B., Nyström, Å., Pettersen, J., Bergman, R. "Experimental design and optimization", Chemometrics and Intelligent Laboratory Systems, 42(1-2), pp. 3-40, 1998. https://doi.org/10.1016/S0169-7439(98)00065-3

[28] TSE, "TS EN 196-1 Methods of testing cement - Part 1: Determination of strength", Turkish Standards Institution, Ankara, Turkey, 2009.

[29] Richter, P. H. "Estimating Errors in Least-Squares Fitting", NASA, Washington, DC, USA, Rep. 42-122, 1995.
[30] Peqini, K., Duka, B., Dominici, G. "Crustal field recovery and secular variation from regional and global models over Albania", Annals of Geophysics, 61(1), GM101, 2018.

https://doi.org/10.4401/ag-7419

[31] Obonyo, E., Kamseu, E., Melo, U. C., Leonelli, C. "Advancing the Use of Secondary Inputs in Geopolymer Binders for Sustainable Cementitious Composites: A Review", Sustainability, 3(2), pp. 410423, 2011.

https://doi.org/10.3390/su3020410

[32] Bernal, S. A., Provis, J. L., Walkley, B., San Nicolas, R., Gehman, J. D., Brice, D. G., Kilcullen, A. R., Duxson, P., van Deventer, J. S. J. "Gel nanostructure in alkali-activated binders based on slag and fly ash, and effects of accelerated carbonation", Cement and Concrete Research, 53, pp. 127-144, 2013.

https://doi.org/10.1016/j.cemconres.2013.06.007

[33] Provis, J. L., Myers, R. J., White, C. E., Rose, V., Van Deventer, J. S. J. "X-ray microtomography shows pore structure and tortuosity in alkali-activated binders", Cement and Concrete Research, 42(6), pp. 855-864, 2012.

https://doi.org/10.1016/j.cemconres.2012.03.004

[34] TSE "TS EN 1015-3 Methods of test for mortar for masonry - Part 3: Determination of consistence of fresh mortar (by flow table)", Turkish Standards Institution, Ankara, Turkey, 2000.

[35] Collins, F., Sanjayan, J. G. "Early Age Strength and Workability of Slag Pastes Activated by $\mathrm{NaOH}$ and $\mathrm{Na}_{2} \mathrm{CO}_{3}$ ", Cement and Concrete Research, 28(5), pp. 655-664, 1998.

https://doi.org/10.1016/S0008-8846(98)00025-8

[36] Nath, P., Sarker, P. K. "Effect of GGBFS on setting, workability and early strength properties of fly ash geopolymer concrete cured in ambient condition", Construction and Building Materials, 66, pp. 163-171, 2014.

https://doi.org/10.1016/j.conbuildmat.2014.05.080

[37] Deb, P. S., Nath, P., Sarker, P. K. "The effects of ground granulated blast-furnace slag blending with fly ash and activator content on the workability and strength properties of geopolymer concrete cured at ambient temperature", Materials \& Design (1980-2015), 62, pp. 32-39, 2014.

https://doi.org/10.1016/j.matdes.2014.05.001

[38] Patankar, S. V., Ghugal, Y. M., Jamkar, S. S. "Effect of Concentration of Sodium Hydroxide and Degree of Heat Curing on Fly Ash-Based Geopolymer Mortar", Indian Journal of Materials Science, 2014, Article ID: 938789, 2014. http://dx.doi.org/10.1155/2014/938789

[39] Part, W. K., Ramli, M., Cheah, C. B. "An overview on the influence of various factors on the properties of geopolymer concrete derived from industrial by-products", Construction and Building Materials, 77, pp. 370-395, 2015. https://doi.org/10.1016/j.conbuildmat.2014.12.065

[40] Katz, A. "Microscopic Study of Alkali-Activated Fly Ash", Cement and Concrete Research, 28(2), pp. 197-208, 1998. https://doi.org/10.1016/S0008-8846(97)00271-8

[41] Patankar, S. V., Jamkar, S. S., Ghugal, Y. M. "Effect of sodium hydroxide on flow and strength of fly ash based geopolymer mortar", Journal of Structural Engineering, 39(1), pp. 7-12, 2012. 